\title{
MEMPERKOKOH EKONOMI SOSIAL INDONESIA MELALUI KOLABORASI ROCHDALE PRINSIPLE DAN KARAKTERISTIK MASYARAKAT NELAYAN
}

\author{
Insan Tajali Nur \\ Program Dokor Ilmu Hukum \\ Fakultas Hukum, Universitas Sebelas Maret \\ insan.tn@gmail.com \\ Aditia Syaprillah \\ Program Dokor Ilmu Hukum \\ Fakultas Hukum, Universitas Sebelas Maret \\ adtiasyaprillah29@gmail.com \\ Joko Suhendro \\ Program Dokor Ilmu Hukum \\ Fakultas Hukum, Universitas Sebelas Maret

\section{Hulman Siregar} \\ Program Dokor Ilmu Hukum \\ Fakultas Hukum, Universitas Sebelas Maret
}

DOI: $10.23917 /$ jjr.v10i1.10842

\begin{tabular}{|c|c|}
\hline \multicolumn{2}{|l|}{ Submission } \\
\hline Track: & ABSTRAK \\
\hline $\begin{array}{l}\text { Received: } \\
7 \text { Mei } 2020\end{array}$ & $\begin{array}{l}\text { Tujuan: Artikel ini menganalisis dengan membandingkan } \\
\text { prinsip koperasi (Rochdale Prinsiple) dengan karakteristik } \\
\text { masyarakat nelayan dalam meningkatkan kesejahteraan } \\
\text { masyarakat nelayan }\end{array}$ \\
\hline & Metodologi: Artikel ini merupakan artikel hukum dokrinal. \\
\hline Final Revision: & $\begin{array}{l}\text { Kajian dilakukan dalam bentuk kepustakaan dan peraturan } \\
\text { perundang-undangan (statute), dengan menganalisis data }\end{array}$ \\
\hline 28 Juli 2020 & $\begin{array}{l}\text { melalui penafsiran dan interpretasi. Sasaran dari kajian } \\
\text { ini adalah memberikan pemahaman kepada masyarakat } \\
\text { nelayan bahwa mereka memiliki kemampuan secara }\end{array}$ \\
\hline Available online: & $\begin{array}{l}\text { mandiri untuk bisa mengatur dan meningkatkan ekonomi } \\
\text { mereka melalui koperasi. }\end{array}$ \\
\hline 31 Juli 2020 & $\begin{array}{l}\text { Temuan: Pemerintah harus membangun landasan mental, } \\
\text { spritual dan kesadaran diri melalui pembinaan kepada } \\
\text { Anggota-anggota koperasi Indonesia, terutama pengurus- }\end{array}$ \\
\hline
\end{tabular}




Corresponding
Author:
Aditia Syaprillah
adtiasyaprillah29@gmail.com

pengurusnya agar memiliki kesadaran berkoperasi dan kepercayaan diri yang tinggi sebagai penopang ekonomi sosial. Dan Rochdale Prinsiple telah mencapai kemajuan yang menakjubkan, karena memiliki metode untuk membentuk karakteristik berupa kepercayaan pada kemampuan diri sendiri untuk memperbaiki diri sendiri dan untuk kemakmuran bersama.

Kegunaan: Artikel ini menawarkan konsep Rochdale Prinsiple dalam memberikan kepercayaan, memperbaiki diri dan kemakmuran masyarakat nelayan kepada Pemerintah guna menopang ekonomi sosial di Indonesia.

Kebaruan/Orisinalitas: Masyarakat nelayan memiliki karakteristik yang berbeda dengan masyarakat lainnya dalam mewujudkan kesejahteraan. Dengan menerapkan Rochdale Prinsiple berupa landasan mental kesadaran diri, nilai spritual serta pembinaan Pemerintah dapat memajukan kemakmuran serta meningkatkan kesejateraan masyarakat nelayan.

Keywords: Rochdale Prinsiple, Koperasi dan Masyarakat Nelayan.

\section{PENDAHULUAN}

Wilayah pesisir merupakan wilayah yang memiliki potensi ekonomi yang sangat besar dan belum dikelola secara intensif. Kawasan ini seharusnya dapat dikembangkan sesuai dengan potensi kekayaan alam yang dimilikinya sehingga dapat meningkatkan tarap kehidupan ekonomi masyarakat sekitarnya. Untuk merealisasikan hal tersebut menghadapi banyak kendala diantaranya ada ego sektoral dari pemangku kepentingan yang terkait dengan pengaturan,pengelolaan dan penataan wilayah pesisir, kelautan dan pulau- pulau kecil. Selain itu pemangku kepentingan memiliki kebijakan yang berbeda antara satu yang lain tanpa adanya keterpaduan (ego sektoral), sehingga hal ini memicu perselisihan antar kepentingan dalam mengelola dan pembangunan ekonomi yang ada diwilayah pesisir, kelautan dan pulaupulau kecil. (Herry Yulistiyono, 2009)

Masyarakat nelayan yang tinggal di kawasan pesisir dan mengelola potensi dari sumber daya kelautan yang ada di Indonesia mempunyai kebiasaan dan ciri khas yang berbeda dari masyarakat di bidang lainnya di Indonesia. Beberapa kawasan pesisir yang relatif berkembang pesat, struktur masyarakatnya bersifat heterogen, memiliki etos kerja yang tinggi, 
solidaritas sosial yang kuat terbuka terhadap perubahan dan memiliki karakteristik interaksi sosial yang mendalam. Sekalipun demikian masalah kemiskinan masih mendera sebagian warga masyarakat pesisir, sehingga fakta sosial ini terkesan ironi ditengah-tengah mereka memiliki hasil kekayaan sumber daya pesisir dan lautan yang melimpah ruah.

Negara Indonesia kesulitan melepaskan diri dari belenggu kemiskinan karena mereka didera keterbatasan di bidang kualitas sumber daya manusia, akses dan penguasaan teknologi, pasar dan modal atau pendanaan. Kebijakan dan implementasi program-program pembangunan untuk masyarakat di kawasan pesisir hingga saat ini masih belum optimal dalam memutus mata rantai kemiskinan dan meningkatkan kesejahteraan mereka. Hal ini disebabkan oleh porsi kebijakan pembangunan bidang sosial, ekonomi dan budaya pada masyarakat nelayan cukup banyak dan rumit.

Dengan melihat batasan terkait pengelolaan wilayah pesisir, kelautan dan pulau-pulau kecil diharapkan kebijakan dari pemangku kepentingan dapat menekan resiko pada usaha makro dan mikro khususnya menanggulangi kemiskinan dengan program pemberdayaan kelembagaan ekonomi, pemberdayaan kemampuan masyarakat nelayan, memaksimalkan keberadaan kearifan lokal (local wisdom) yang merupakan landasan mental yang kuat dan potensi lokal (Local potention), Sehingga harapan yang dibangun untuk masyarakat nelayan adalah jalannya ekonomi sosial dan ekonomi berkelanjutan (an social economy and sustainable economy area) guna menunjang kesejahteraan secara optimal, jika mereka mampu menghasilkan barang dan jasa, berkesinambungan (on a continuing basis) menghindarkan ketidakseimbangan ekstrim antar sektor (extreme sectoral embalances) yang dapat menghancurkan produksi sektor primer, sekunder dan tersier. (Fanesa Argomeli, 2014).

Salah satu kendala yang dihadapi masyarakat nelayan dalam upaya mereka untuk meningkatkan taraf hidup adalah sarana alat tangkap yang digunakan masih relatif sederhana. Selain itu terbatasnya akses pendanaan permodalan lembaga keuangan untuk membiayai pengadaan sarana alat tangkap yang akan digunakan. Menurut Najib dalam Rouli Anita Velentina, Sebagian besar kredit sektor kemaritiman masih diperuntukkan untuk perkapalan dan industri pengolahan. Berdasarkan penilaian Bank Indonesia, ada dua penyebab lembaga perbankan kurang berminat untuk menyalurkan pembiayaan ke sektor perikanan tangkap. Pemberian kredit untuk sektor perikanan tangkap dinilai lembaga perbankan memiliki risiko tinggi. Hal ini mengakibatkan penyaluran kredit kepada sektor perikanan tangkap mensyaratkan agunan dengan nilai ekonomis sebesar pinjaman. (Rouli Anita Valentina, 2018) 
Persyaratan pengajuan kredit yang ditentukan perbankan yang mengharuskan adanya jaminan berupa sertifikat tanah atau bukti pemilikan kendaraan bermotor sebagai persyaratan administrasi sulit dipenuhi oleh para nelayan. Akibatnya, para nelayan sulit memperoleh kesempatan untuk mendapatkan pinjaman dari bank untuk membeli perahu dan alat penangkapan ikan yang memadai. Persyaratan tersebut merupakan bagian dari prinsip kehatihatian pada lembaga keuangan dan lembaga pembiayaan khususnya perbanka. Penentuan persyaratan itu bukan tanpa alasan dan pertimbangan bagi perbankan yang harus menjaga kepercayaan dengan mengedepankan prinsip kehati-hatian. Sulit bagi perbankan untuk bisa meyakini kelancaran pengembalian pinjaman tanpa adanya jaminan dari nelayan sebagai pemohon kredit. Selain itu bank atau lembaga keuangan umumnya telah mempunyai catatan profil nasabah nelayan yang ingkar janji (wanprestasi) dan tidak tertib dalam pembayaran angsuran pinjamannya.

Persepsi yang berkembang dan melekat pada masyarakat nelayan bahwa masyarakat tidak gemar menabung, kebutuhan tak terduga dan kenaikan harga alat dan bahan untuk menangkap ikan semakin membuat ekonomi nelayan sulit tidak meningkat . Selain itu, usaha perikanan tangkap merupakan usaha yang berisiko tinggi yang memerlukan tempat penyimpanan khusus.. Keberhasilan usaha ini kadang tidak terlepas dari faktor-faktor diluar kendali manusia, seperti kondisi cuaca, perubahan alam sekitar pesisir akibat gempa bumi, pasang surut, bahkan kerusakan alam akibat pihak pihak yang tidak bertanggung jawab. Kemudian, faktor lainnya seperti hasil tangkapan yang tergolong dalam komoditas yang mudah rusak sehingga memerluan alat penyimpanan khusus.

Dari uraian tersebut di atas peranan negara sebagai regulator dan pemangku kepentingan sangat diperlukan melalui kebijakan anggaran dari APBN maupun perbankan untuk menyediakan dan mengalokasikan dana pinjaman bagi masyarakat nelayan. Berdasarkan itu dirumuskan permasalahan:

1. Bagaimana Konsep Pembangunan Ekonomi Sosial Melalui Koperasi di Indonesia?

2. Apakah Prinsip Koperasi (Rochdale Prinsiple) dengan Karakteristik Nelayan dapat diterapkan untuk mengatasi kendala ekonomi masyarakat nelayan?

\section{METODELOGI PENELITIAN}

Kajian ini menggunakan metode hukum doktrinal, Kajian ini dilakukan berdasarkan studi kepustakaan dengan inventarisasi dari hukum positif, pengumpulan bahan- bahan hukum 
berkaitan dengan falsafah, nilai dan perbandingan, sejarah dan Peraturan PerundangUndangan, nilai moral serta nilai- nilai Pancasila yang dikaitkan dengan lingkup Perpaduan Pembangunan Ekonomi Sosial melalui Koperasi (Rochdale Prinsiple) dan Karakateristik Masyarakat adat nelayan. Kajian ini dilakukan dengan menganaliasa data dalam bentuk panafsiran (intepretasi) historical/ sejarah, gramatikal serta teologis/ futuristik. Sehingga keluaran kajian ini sasarannya adalah peran pemerintah sebagai pemangku kepentingan memberikan pemahaman kepada masyarakat nelayan untuk dapat menerapkan kemampuan sendiri maupun secara bersama melalui pengembangan wadah koperasi yang dapat meningkatkan taraf hidup ekonomi masyarakat nelayan wilayah pesisir.

\section{PEMBAHASAN}

\section{Konsep Pembangunan Ekonomi Sosial Melalui Koperasi di Indonesia}

Koperasi di Indonesia merupakan soko guru, sistem ekonomi yang hendak dikembangkan adalah "ekonomi mutualisme" atau "ekonomi gotong royong" dari seluruh warga negara bangsa Indonesia yang dilandasi oleh asas kekeluargaan. Dari amanat Pasal 33 Undang-Undang Dsasar Negara Repubik Indonesia Tahun 1945 (UUD NRI 1945) diarahkan pembangunan koperasi di Indonesia diarahkan untuk mengembangkan demokrasi ekonomi yang adil dan beradab yaitu demokrasi ekonomi yang dapat mewujudkan kemakmuran dan keadilan sosial bagi seluruh rakyat Indonesia, bukan kemakmuran orang atau seorang. Pasal 33 UUD NRI Tahun 1945, harus dihayati dan diamalkan dalam kehidupan berbangsa dan bernegara khususnya di bidang perekonomian nasional, terkait dengan koperasi harus mampu menjadi alat atau wadah untuk melaksanakan ketentuan dan dari Pasal 33 UUD NRI Tahun 1945 tersebut.

Pasal 1 ayat 1 Undang- Undang Nomor 25 Tahun 1992 Tentang Perkoperasian (UU No. 25 Tahun 1992 tentang Perkoperasian), menyebutkan Koperasi adalah badan usaha yang beranggotakan orang-seorang atau badan hukum koperasi dengan melandaskan kegiatannya berdasarkan prinsip koperasi sekaligus sebagai gerakan ekonomi rakyat yang berdasar atas asas kekeluargaan. Secara filosofi, koperasi merupakan badan usaha dengan status badan hukum sebagai gerakan ekonomi rakyat yang memiliki tujuan untuk meningkatkan kesejahteraan anggota koperasi (secara khusus) dan meningkatkan kesejahteraan masyarakat (secara umum), serta ikut membangun tatanan perekonomian nasional dalam rangka 
mewujudkan masyarakat yang maju, adil dan makmur berdasarkan Pancasila dan UUD NRI Tahun 1945

Pengaturan mengenai koperasi di Indonesia dapat ditemukan di dalam UU No. 25 Tahun 1992 tentang Perkoperasian. Di tahun 2012 dibentuklah undang-undang yang mengatur perkoperasian sebagai pengganti undang-undang koperasi tahun 1992 yaitu Undang-Undang Nomor 17 Tahun 2012 tentang Perkoperasian, di tahun 2013 Mahkamah Konstitusi dengan putusannya Nomor 28/PUU-XI/2013 membatalkan secara keseluruhan UU No. 17 Tahun 2012 tentang Perkoperasian. Konsekuensi dari putusan Mahkamah Konstitusi tersebut kembalinya pengaturan koperasi kepada UU No. 25 Tahun 1992 tentang Perkoperasian. Walaupun hukum positif diatas merupakan perwujudan negara dalam memperhatikan pembangunan ekonomi bagi masyarakat nelayan, tetapi yang perlu menjadi penekan sebagai perwujudan pelaksanaan ekonomi sosial maka, pengaturan tersebut harus memiliki nilai keseimbangan atau memproposionalkan pengaturan ekonomi bersama dengan ekonomi sosial. Seperti apa yang dijelaskan oleh Ricrad A Posner bahwa: Prinsip Equilibrium Composition (komposisi keseimbangan), kesenjangan rasionalitas terhadap definisi, persepsi kepentingan dan tujuan yang pada dasarnya terbagi menjadi 2 (dua) kriteria, yaitu kriteria untuk kepentingan rakyat dan untuk kepentingan negara. (Fajar Sugianto, 2014).

Dengan demikian, terkait dengan peraturan perundang-undangan mengenai Perkoperasian, diperlukan penyamaan persepsi antara apa yang diinginkan oleh negara selaku pemangku kepentingan melalui peraturan perundang-undangan dan kebijakan dan apa yang dibutuhkan masyarakat nelayan. Sehingga dapat mempertemukan keseimbangan komposisi kepentingan dan tujuan bersama antara pemerintah dan masyarakat. Paradigma masyarakat nelayan dan Pemerintah dalam menjalankan produk hukumnya memiliki paradigma yang sama yang sebenarnya sudah tercantum dalam hukum positif dan kriteria masyarakat adat nelayan itu sendiri.

Bahwa produk hukum yang dibentuk oleh pemerintah diharapkan memberikan keuntungan bagi masyarakat pesisir dan pemerintah. Secara rasional masyarakat pesisir harus bisa menerima produk hukum yang sudah dibentuk oleh pemerintah, apabila produk hukum tersebut merugikan masyarakat pesisir, maka berdampak terhadap masyarakat pesisir misalnya jangan pernah berharap terjadinya peningkatan kesejahteraan masyarakat pesisir dengan tidak diperolehnya akses keadilan bagi masyarakat pesisir. (Romli Atmasasmita, 2017). 


\section{Prinsip-Prinsip Koperasi Secara Umum (Rochdale Prinsiple)}

Prinsip koperasi dengan pendekatan kelompok masyarakat nelayan yang sebagai pelaku utama dalam kegiatan ekonomi yang diarahkan agar mampu mengelola sumber daya yang ada dalam rangka meningkatkan, melindungi, mencerdaskan dan mensejahterahkan anggota maupun masyarakat secara berkelompok dan berkelanjutan. Prinsip koperasi Indonesia yang merupakan adopsi dari Rochdale Prinsiple yang merupakan dasar dasar bagi koperasi diseluruh dunia yang berlaku secara universal. (Sagimun MD, 1983/1984) Menurut Christopher S. Axworthy:

"Co-operatives are distinguishable from profit-making businesses in a number of ways. For instance, they are not established for a speculative purpose and so are not profit-making as such. The only meaningful way in which to define a co-operative, however, is in the context of the Rochdale Principles. These are the guiding principles of the co-operative movement laid down in 1844 by the Rochdale Society of Equitable Pioneers"

" koperasi dibedakan dari bisnis yang menghasilkan laba dalam sejumlah cara. Misalnya, mereka tidak dibuat untuk spekulatif tujuan dan tidak menghasilkan laba seperti itu. Satu-satunya cara yang bermakna dalam yang mendefinisikan koperasi, bagaimanapun, adalah dalam konteks Rochdale Prinsip Ini adalah prinsip-prinsip panduan gerakan koperasi turun pada tahun 1844 oleh Rochdale Society of Equitable Pioneers. (Christopher S Axworthy, 1977: 137 - 138).

Dengan melaksanakan keseluruhan prinsip tersebut koperasi mewujudkan dirinya sebagai badan usaha sekaligus sebagai gerakan ekonomi yang berwatak sosial. Prinsip koperasi secara global kemudian diturunkan kedalam hukum Positif Indonesia yaitu UU No.

25 Tahun 1992 tentang Perkoperasian mulai diberlakukan, adapun prinsip-prinsipnya ialah:

a. keanggotaan bersifat sukarela dan terbuka;

mengandung makna bahwa menjadi anggota Koperasi tidak boleh dipaksakan oleh siapapun. Sifat kesukarelaan juga mengandung makna bahwa seorang anggota dapat mengundurkan diri dari koperasinya sesuai dengan syarat yang ditentukan dalam Anggaran Dasar Koperasi. Sedangkan sifat terbuka memiliki arti bahwa dalam keanggotaan tidak dilakukan pembatasan atau diskriminasi dalam bentuk apapun.

b. pengelolaan dilakukan secara demokrasi;

menunjukan bahwa pengelolaan Koperasi dilakukan atas kehendak dan keputusan para anggota. Para anggota itulah yang memegang dan melaksanakan kekuasaan tertinggi dalam koperasi.

c. pembagian SHU dilakukan secara adil sesuai dengan jasa usaha masing-masing anggota; pembagian sisa hasil usaha kepada anggota dilakukan tidak semata-mata berdasarkan modal yang dimiliki seseorang dalam koperasi tetapi juga berdasarkan perimbangan jasa 
usaha anggota terhadap koperasi. ketentuan ini merupakan perwujudan nilai kekeluargaan dan keadilan

d. pemberian balas jasa yang terbatas terhadap modal; dan modal dalam koperasi pada dasarnya dipergunakan untuk kemanfaatan anggota dan bukan untuk sekedar mencari keuntungan. Oleh karena itu balas jasa terhadap modal yang diberikan kepada para anggota juga terbatas dan tidak didasarkan semata-mata atas besarnya modal yang diberikan. Yang dimaksud dengan terbatas adalah wajar dalam arti tidak melebihi suku bunga yang berlaku di pasar.

e. kemandirian.

kemandirian mengandung pengertian dapat berdiri sendiri, tanpa bergantung pada pihak lain yang dilandasi oleh kepercayaan kepada pertimbangan, keputusan, kemampuan, dan usaha sendiri. Dalam kemandirian terkandung pula pengertian kebebasan yang bertanggung jawab, otonomi, swadaya, berani mempertanggungjawabkan perbuatan sendiri, dan kehendak untuk mengelola diri sendiri.

Dengan demikian prinsip- prinsip koperasi yang dapat diterapkan dalam peningkatan kesejahteraan masyarakat nelayan ialah:

a. Mengutamakan musyawarah dalam mengambil keputusan untuk kepentingan bersama; dan

b. Kekeluargaan dan kebersamaan anggota koperasi dalam bentuk hak dan kewajiban yang sama untuk meningkatkan kesejahteraan anggota.

\section{Hubungan Erat Prinsip Koperasi (Rochdale Prinsiple) Indonesia Dengan Karakteristik} Masyarakat Nelayan dalam Meningkatkan Kesejahteraan Masyarakat Nelayan Koperasi di Indonesia Sebagai Organisasi demokratis dan berwatak sosial Untuk Mayarakat Nelayan.

Koperasi di Indonesia secara nyata merupakan kumpulan dari masyarakat yang miliki penghasilan yang taraf hidupnya menengah dan rendah dan saling bekerja sama untuk memperbaiki taraf ekonominya untuk lebih baik dan juga merupakan bentuk suatu badan usaha sekaligus berbadan hukum. Artinya, selain bersifat dan bertindak dari suatu perkumpulan atau persekutuan biasa, koperasi juga melaksanakan beraktivitas yang berorientasi pada ekonomi sosial. Anggota koperasi bekerjasama dalam menyelenggarakan produksi, pembelian, penjualan, simpan-pinjam, pemberian jasa dan lain sebagainya. Koperasi di Indonesia juga menyelenggarakan kegiatan di bidang ekonomi. Namum koperasi Indonesia tidak boleh meninggalkan asasnya yaitu azas koperasi Indonesia adalah kekeluargaan dan gotong royong. 
Demikian kultur masyarakat Indonesia khususnya masyarakat nelayan yang masih diwarnai kehidupannya dengan nuansa tradisional dan adat yang berlaku maka, koperasi mampu menjawab persoalan pembangunan ekonomis sosial di Indonesia, jika dicermati, kultur masyarakat Indonesia. Pada hakikatnya memiliki nilai-nilai yang senantiasa diwariskan, ditafsirkan, dan dilaksanakan seiring dengan proses perubahan sosial kemasyarakatan. Pelaksanaan nilai-nilai budaya merupakan manifestasi, dan legitimasi masyarakat terhadap budaya. Eksistensi budaya dan keragaman nilai-nilai luhur kebudayaan yang dimiliki oleh bangsa Indonesia merupakan sarana dalam membangun karakter warga negara, baik yang berhubungan dengan karakter privat maupun karakter publik. (Rasid Yunus, 2014)

Hal ini bisa kita lihat bahwa masyarakat nelayan dalam memilih koperasi sebenarnya merupakan hal yang tepat mengingat terdapat irisan prinsip yaitu:

1) Adanya Organisasi Sosial,

2) Demokartis,

3) Orientasi Pada Sistem Pengetahuan,

4) Kerjasama,

5) Kepercayaan Terhadap Kekuatan Alam Dan Lingkungan

Hal ini bukan tanpa alasan karena negara Indonesia, Secara kenyataan apabila melihat rujukan dari Kusnadi dalam Fanesa argomeli, menyatakan bahwa bangsa Indonesia memiliki entitas sosial, khususnya masyarakat nelayan memiliki sistem budaya dan nilai spritual dan mental yang kuat. Masyarakat nelayan secara umum memiliki pola interaksi yang sangat mendalam, pola interaksi yang dimaksud dapat dilihat dari hubungan kerjasama dalam melaksanakan aktifitas, melaksanakan kontak secara bersama baik antara nelayan dengan nelayan maupun dengan masyarakat lainnya, mereka memiliki tujuan yang jelas dalam melaksanakan usahanya serta dilakukan dengan sistem yang permanen, sesuai dengan kebudayaan pada masyarakat nelayan. (Fanesa Argomeli, 2014).

Terkait prinsip utama koperasi karakter masyarakat nelayan yang bernuansa tradisional ternyata karakteristik komunitas tersebut beririsan dengan prinsip koperasi atau "Rochdale Prinsiple". Hal ini dapat membuktikan bahwa modal didalam watak masyarakat nelayan memiliki hubungan erat atau persamaan dengan koperasi sebagai soko guru dalam pembangunan ekonomi sosial yang dapat dibagi menjadi dibagi menjadi 3 bagian yaitu: (1) Modal mental; (2) Modal moral ( norma sosial); dan (3) Modal uang. 
Bagi para anggotanya modal pada poin 1 dan poin 2 merupakan hal yang lebih penting daripada poin 3. Dengan kesadaran berkoperasi dan harga diri yang merupakan pengembangan dari Rochdale pioneers telah berhasil dengan gilang-gemilang meningkatkan taraf hidup serta kedudukan ekonomi anggotanya-anggotanya. Bahkan "koperasi Rochdale" telah berhasil memajukan kemakmuran serta meningkatkan kesejahteraan masyarakat. Adapun dasar- dasar "koperasi Rochdale" adalah sebagai berikut:

1) Masuk dan berhenti menjadi anggota atas dasar sukarela.

2) Satu anggota, satu hak suara

3) Koperasi netral terhadap agama dan politik

4) Pembelian dan penjulan secara tunai

5) Pembagian keuntungan atau hasil usaha koperasi menurut jasa anggota- anggota

6) Harga penjualan disamakan dengan harga pasar setempat.

7) Kualitas, ukuran, takaran, dan timbangan barang harus dijamin.

8) Penyelenggaraan pendidikan bagi anggota koperasi. (Sagimun MD, 1983/1984)

Berikut alasan bahwa koperasi Indonesia masih patut menjadikan Rochdale Prinsiple sebagai dasar dalam menjalankan koperasi Indonesia untuk mampu dididik, bertanggung jawab, percaya diri dengan bermodalkan pada pada nilai mental, moral dan lebih penting dari orientasi nilai kapital atau uang (kapitalisme):

a) Landasan idiil koperasi Indonesia adalah Pancasila.merupakan falsafat negara Republik Indonesia dan sudah menjadi pedoman dalam kehidupan bagi para anggota koperasi untuk menghayati dan mengamalkan nilai nilai yang terkandung dalam sila- sila Pancasila.

b) Landasan Struktural Koperasi Indonesia adalah Undang- Undang Dasar Negara Republik Indonesia Tahun 1945, Seperti halnya juga Pancasila, Pasal 33 Undang- Undang dasar Negara Republik Indonesia Tahun 1945 merupakan pedoman bagi anggota koperasi.yang bertumpu pada asas kekeluargaan.

c) Landasan Operasional Koperasi Indonesia :

1) Pasal 33 Undang- Undang Dasar Negara Republik Indonesia Tahun 1945;

2) Undang- Undang Koperasi Nomor 25 Tahun 1992 tentang Perkoperasian;

3) Anggaran Dasar dan Anggran Rumah Tangga Koperasi

Dari ketiga landasan seharusnya tidak akan mengalami hambatan, apalagi tantangan dari pihak siapa atau manapun seperti hal nya telah menjamur lembaga keuangan dan lembaga pembiayaan atau pihak luar lainnya yang memang memiliki sumber permodalan yang cukup 
besar tetapi juga memiliki resiko yang cukup riskan pula. Bahkan pemerintah berkewajiban untuk memberikan pendidikan biak formal maupun informal, bimbingan, penyuluhan, pengawasan, dan perlindungan kepada koperasi Indonesia, agar Koperasi Indonesia mampu menjamin kemajuan dan kesejahteraan bersama.

Kesejahteraan merupakan suatu kosekuensi negara yang berdasarkan pada welfare state yang dicetuskan R. Kranenburg, diaman negara kesejahteraan (walfare state) menjamin terselenggaranya kesejahteraan rakyat yang diwujudkan dalam lima pilar kenegaraan, yaitu: Demokrasi (Democracy). Penegakan Hukum (Rule of Law), perlindungan Hak Asasi Manusia, Keadilan Sosial (Social Juctice) dan anti diskriminasi. Konsep kesejahteraan negara tidak hanya mencakup deskripsi mengenai sebuah cara pengorganisasian kesejahteraan (welfare) atau pelayanan sosial (social services). Melainkan juga sebuah konsep normatif atau sistem pendekatan ideal yang menekankan bahwa setiap orang harus memperoleh pelayanan sosial sebagai haknya yang diatur dalam konstitusi. Maka akan sangat ceroboh jika pembangunan ekonomi dinafikan, kemudian pertumbuhan ekonomi hanya dipandang dan dikonsentrasikan pada angka persentase belaka. (Susilo Wardani, 2017)

Kesejahteraan rakyat adalah indikator yang sesungguhnya. Seperti yang dianjurkan oleh Presiden Suharto:

"Koperasi harus menjadi sokoguru ekonomi nasional yang menjamin kemajuan dan kemakmuran bersama. Pemerintah dan rakyat Indonesia harus berusaha agar koperasi Indonesia benar-benar mampu melaksanakan Pasal 33 UUD NRI Tahun 1945”.

Koperasi Indonesia harus dibuat mampu turut mewujudkan masyarakat Indonesia yang adil dan makmur berdasarkan Pancasila dan Undang-Undang Dasar Negara Republik Indonesia Tahun 1945. Alasan Keterlibatan Pemerintah Indonesia berkewajiban untuk mengayomi masyarakat nelayan menurut Kusnadi dalam Fanesa argomeli karena masyarakat nelayan menghadapi sejumlah masalah politik, sosial dan ekonomi yang kompleks. Masalahmasalah tersebut antara lain: (Fanesa Argomeli, 2014: 6).

"Kemiskinan, kesenjangan sosial dan tekanan-tekanan ekonomi yang datang setiap saat, Keterbatasan akses modal, teknologi dan pasar sehingga memengaruhi dinamika usaha, Kelemahan fungsi kelembagaan sosial ekonomi yang ada, Kualitas sumberdaya manusia yang rendah sebagai akibat keterbatasan akses pendidikan, kesehatan, dan pelayanan degradasi sumberdaya lingkungan baik di kawasan pesisir, laut, maupun pulau-pulau kecil, dan lemahnya kebijakan yang berorientasi pada kemaritiman sebagai pilar utama pembangunan nasional". 


\section{Urgensi Untuk Memperkokoh Karakteristik Masyarakat Nelayan dengan Berkolaborasi Prinsip Koperasi Indonesia Saat Ini.}

Oleh karena itu Koperasi di Indonesia perlu menjadi bagian dalam menjalankan ekonomi sosial bagi masyarakat Nelayan mengingat saat ini:

a) Pentingnya Pemberdayaan bagi kelompok nelayan dalam meningkatkan taraf hidup, Untuk memenuhi kebutuhan hidup sehari-hari terutama dalam pemenuhan kebutuhan dasar masih sangat terbatas. Keterbatasan tersebut juga dipengaruhi oleh rendahnya tingkat pendapatan yang dimiliki oleh sebagian besar kelompok nelayan yang disebabkan pula oleh akses produksi perikanan/hasil tangkapan yang sedikit.

b) Mengembangkan peran teknologi hasil tangkapan, kemudian dari aspek teknologi sebagian besar dari mereka masih menggunakan teknologi tradisional, seperti alat pancing, menggunakan dayung.

c) Perlunya pemberian akses modal mudah dan ringan.

d) Mengembangkan sarana pemasaran, pemasaran hanya terbatas di sekitar areal wilayah Kecamatan ataupun hanya mengandalkan pasar lokal (Fanesa Argomeli, 2014: 6).

Pemangku kepentigan dan koperasi di Indonesia harus diberi landasan mental. Anggota-anggota koperasi Indonesia, terutama pengurus-pengurusnya harus diusahakan agar memiliki kesadaran berkoperasi dan harga diri yang tinggi. Anggota- anggota Koperasi Indonesia harus memiliki kepercayaan akan kemampuan yang ada pada diri mereka sendiri. Landasan mental ini diperlukan oleh Koperasi Indonesia untuk menghadapi dan mengatasi segala rintangan dan hambatan. Landasan mental itu mutlak harus ada bagi koperasi Indonesia untuk meningkatan tarap hidup dan kemakmuran bersama. (Sagimun MD, 1983/1984)

Dasar dan kekuatan koperasi yang utama adalah semangat menolong diri dengan kemampuan yang ada pada diri sendiri. Seperti halnya "Koperasi Rochdale" yang telah mencapai kemajuan yang menakjubkan karena adanya kepercayaan kepada kemampuan diri sendiri untuk memperbaiki diri sendiri dan kemakmuran bersama. Seandainya dari pihak manapun termasuk asing yang menyatakan koperasi harus hidup dan dibantu dan tidak perlu bekerja secara efisien, maka pendapat itu sangat bertentangan dengan dasar dan semangat koperasi yang justru atas dasar kepercayaan pada kemampuan diri sendiridan moral harus dapat memperbaiki nasib anggota-anggota dan memajukan kemakmuran rakyat. Hal diatas bisa dibuktikan dengan karakteristik masyarakat nelayan yang merupakan komunitas yang memiliki potensi untuk bisa membangkitkan badan usaha koperasi lebih baik dibandingkan 
mereka memiliki ketergantungan dengan pihak luar yang berorientasi hanya pada keuntungan belaka, seperti lembaga keuangan dan lembaga pembiayaan bahkan rentenir, Hal ini bisa kita lihat dari karakteristik sosial budaya masyarakat nelayan yang memiliki modal mental, moral dan spritual yang kuat yang memang nantinya melahirkan bentuk stratifikasi sosial yang permanen dan saling berkolaborasi dengan prinsip koperasi (Rochdale Prinsiple ) yaitu:

(1) Masyarakat yang turut memberikan andil terhadap aktivitas dibidang perikanan untuk menyediakan peralatan, modal, bahkan disebut juga kelompok elit desa yang mampu menggerakan perekonomian pedesaan.

(2) Pengembangan pengetahuan tentang perkoperasian

(3) Pengembangan jiwa motivasi untuk mendirikan koperasi

(4) Pengembangan ketrampilan nelayan terutama tentang perkoperasian.

(5) Pengembangan perkoperasian yang berjiwa koperasi dan padat karya.

(6) Pengembangan akses pemasaran

(7) Penguatan Kelembangan informal dalam masyarakat

(8) Pembangunan sarana penunjang usaha perikanan

(9) Pengelolaan sumber daya perikanan berbasis masyarakat. (Iin Indarti, 2015)

\section{KESIMPULAN}

Wilayah pesisir dan pulau pulau kecil yang tersebar diseluruh di seluruh Indonesia merupakan wilayah yang memiliki potensi ekonomi yang dapat dikembangkan dengan berbagai sektor usaha. Potensi ekonomi tersebut belum sepenuhnya dikembangkan untuk meningkatkan taraf hidup ekonomi masyarakat nelayan disekitarnya.

Koperasi adalah soko guru dalam pengembangan ekonomi Negara Kesatuan Republik Indonesia sebagai mana diamanatkan dalam Pasal 33 Undang-Undang Dsasar Negara Repubik Indonesia Tahun 1945. Konsep pembangunan ekonomi sosial dengan prinsip koperasi atau "Rochdale Prinsiple” tepat untuk diterapkan dalam upaya meningkatkan taraf hidup ekonomi masyarakat nelayan wilayah pesisir dengan dukungan pemerintah sebagai pemangku kepentingan untuk dapat menentukan dan mengarahkan kebijakan/peraturan yang terintegrasi dan penyediaan dana pinjaman bagi nelayan melalui APBN atau perbankan.

Prinsip koperasi atau “Rochdale Prinsiple” yang selalu mengedepankan musyawarah, kekeluargaan dan kebersamaan seirama dengan karekteristik yang sudah melekat dan terbangun dalam kehidupan sosial masyarakat nelayan wilayah pesisir, Hal ini menjadi faktor 
penguat untuk menerapkan koperasi sebagai wadah untuk meningkatkan taraf kehidupan dan ekonomi nelayan dengan peran aktif pemerintah sebagai pemangku kepentingan melalui pembinaan kepada anggota-anggota koperasi Indonesia, terutama pengurus-pengurusnya agar memiliki kesadaran berkoperasi dan kepercayaan diri yang tinggi sebagai penopang ekonomi sosial.

\section{REFERENCES}

Brett Fairbairn. (no year). The Meaning of Rochdale:The Rochdale Pioneers and the Cooperative Principles. Occasional Paper Series. Centre For Teh Study Of Cooperatives", University Of Saskatchewan.

Christopher S. Axworthy, (1977) Consumer Co-Operatives And The Rochdale Prniciples Today. Osgoode Hall Law Journal, Vol 15 No 1

Fanesa Argomeli. (2014). Interaksi Kelompok Nelayan Dalam Meningkatkan Taraf Hidup Di Desa Tewil Kecamatan Sangaji Kabupaten Maba Halmahera Timur. Journal Acta Diurn. Vol III No 3

Fajar Sugianto. (2014). Economic Analysis of Law Seri Analisis Ke-ekonomian Tentang Hukum Seri I Pengantar. Jakarta: Kencana,

Herry Yulistiyono. (2009). Evaluasi Penguatan Kelembagaan Koperasi Masyarakat Nelayan di Kabupaten Bangkalan. Media Trend, Vol 4 No 1

Iin Indarti. (2015). Model Peningkatan Kesejahteraan Masyarakat Pesisir Melalui Penguatan Kelembagaan Koperasi Nelayan Berkelanjutan”. Jurnal Dinamika Ekonomi \& Bisnis, Vol. 12 No. 1

M. Munandar Sulaeman, (2012), Ilmu Budaya Dasar, Pengatar Ke Arah Ilmu Sosial Budaya Dasar/ISBD, Bandung: PT. Rafika Aditama.

Rasid Yunus, (2014), Nilai-Nilai Kearifan Lokal (Local Genius) Sebagai Penguat Karakter Bangsa Studi Empiris Tentang Huyula, Jogjakarta: Deepablish.

Romli Atmasasmita dan Kodrat Wibowo. (2017). Analisis Ekonomi Mikro Tentang Hukum PIdana Indonesia. Jakarta: Kencana.

Sagimun MD. (1983/1984). Koperasi Indonesia (Bacaan Populer untuk Perguruan Tinggi), Proyek Penulisan dan Penerbitan Buku/Majalah Pengetahuan Umum dan Prosesi, Jakarta: Departemen Pendidikan dan Kebudayaan.

Susilo Wardani. (2017). Kebijakan Perizinan Pengembangan Umkm Sebagai Upaya Mewujudkan Negara Kesejahteraan Di Era Liberalisasi Ekonomi Global, Prosiding Seminar Nasional. Surakarta: Universitas Muhammadiyah Press 
Rouli Anita Velentina. (2018). Kebijakan Pembiayaan Bagi Nelayan Tradisional. MasalahMasalah Hukum, Jilid 47 No 3.

Undang- Undang Dasar Negara Republik Indonesia Tahun 1945.

Undang-Undang Nomor 25 Tahun 1992 tentang Perkoperasian.

Laporan Akhir Penyelarasan Naskah Akademik Rancangan Undang-Undang Tentang Perkoperasian, Badan Pembinaan Hukum Nasional, Kementerian Hukum Dan Hak Asasi Manusia, 2015. 